\title{
Ivory Coast Intra Regional Trade: The Role of Infrastructure and Economic Environment
}

\author{
FE Doukouré Charles \\ National School of Statistics and Applied Economics; \\ Economic Policy Analysis Unit of the Ivoirian Center of Economic and Social Research, Abidjan, Ivory Coast
}

\begin{abstract}
Intra-regional trade dynamic can foster economic integration with a contribution of the lead economy. In that way, infrastructure and economic environment play an important role in expanding trade by reducing trade costs. This paper examines the role of infrastructure and the economic environment on Ivory Coast intra-regional trade. The study performs a transformed and advanced gravity model, using panel data over the period 1996 to 2013 , modelling exports of Ivory Coast. The analysis shows exports towards the other member states of West African Economic and Monetary Union (WAEMU) depend significantly on the availability of transport and communication infrastructures developed as well as variables such as Gross Domestic Product growth, economic similarity within countries, Foreign Direct Investment (FDI) net inflows in Ivory Coast. Estimations point out that indeed, the level of economic growth in the other member countries, Foreign Direct Investment (FDI) net inflows in Ivory Coast, the number of mobile phone subscribers per 100 inhabitants in Ivory Coast and the proportion of paved roads, have a positive impact on Ivory Coast intra-regional trade.
\end{abstract}

Keywords: intra-regional trade, infrastructure, economic environment, transformed gravity model

\section{Introduction}

Since 1994, the West African Economic and Monetary Union (WAEMU) has implemented policies aimed at strengthening economic integration within members' states through intra-WAEMU trade facilitation policies. Then the implementation of the Common External Tariff (CET) enabled the WAEMU Economic Committee to better show its intention to accelerate growth and consolidate the convergence of economies. Despite these efforts, it is clear that intra-WAEMU trade is still weak compared to other Regional Economic Communities (RECs) in sub-Saharan Africa and even in the world. WAEMU intra-trade remains stable between $14 \%$ and $15 \%$ of the total trade. In sub-Saharan Africa for example, EAC (East African Community) accounted for 21\%, $18 \%$, and $18 \%$ of intra-trade, respectively, in 2012, 2013, and 2014. And intra-trade in SADC (Southern African Development Community) represents 18\%,19\%, and 19\% respectively over the same period. Other regional economic communities in Sub-Saharan Africa perform poorly in terms of both intra-trade and intra-WAEMU trade. In the rest of the world, among developed countries, the situation is very different. For example, ASEAN (Association of Southeast Asian Nations) recorded between 26\% and 25\% of intra-trade

FE Doukouré Charles, assistant lecturer, National School of Statistics and Applied Economics, a member of Economic Policy Analysis Unit of the Ivoirian Center of Economic and Social Research, Abidjan, Ivory Coast.

Correspondence concerning this article should be addressed to FE Doukouré Charles, National School of Statistics and Applied Economics, 08 BP 03, Abidjan 08, Ivory Coast. 
between 2012 and 2014, respectively. The NAFTA (North American Free Trade Agreement) and the European Union (EU) of 28 countries are still better with $49 \%, 49 \%$, and $50 \%$ of trade between members and $62 \%, 61 \%$, and 63\% of intra-trade, respectively between 2012 and 2014 (UNCTAD, 2016).

Moreover, in all of these RECs, there is a leading economy that drives economic growth and expansion of intra-regional trade. And that results in generating positive externalities across all member countries. For example, economic growth in the EU is driven by Germany's performance. In ASEAN, it is Indonesia with just over $40 \%$ of regional GDP, which is the leader of this union. Growth in these leading countries leads to positive externalities across the zone on the one hand and their intra-zone trade is significant. In WAEMU, the situation is somewhat different. Ivory Coast is the driving economy of course, with $34 \%$ of the nominal GDP of the zone in 2014. But between 2012 and 2014 intra-WAEMU trade has stagnated between $14 \%$ and $15 \%$ of total trade and the intra-WAEMU trade share of Ivory Coast dropped between 1996 and 2014. In addition, economic growth in Ivory Coast over the last five years is on average $8 \%$ and about $6 \%$ for WAEMU (International Monetary Fund, 2016). In this logic, the integration process produces positive effects on the volume of trade between member states of RECs and especially between the center and the periphery (Egger \& Pfaffermayr, 2013). According to the literature on the geographical economy, the center designates the leading economy whose performances produce positive externalities on the periphery, the other members of the REC via agglomeration effects.

Thus these agglomeration effects created by the center have positive impacts on the periphery. The drivers of these positive externalities include infrastructure, the macroeconomic environment. In the case of WAEMU, it is noted that the economic and trade performance are highly correlated with those of Ivory Coast and its contribution to intra-community trade. Political instability in Ivory Coast affects the performance of the union and the expansion of foreign trade (Nayo \& Egoumé-Bossogo, 2011). Unfortunately, although intra-WAEMU trade appears to be increasing, the share of Ivory Coast intra-trade tends to decline over time (UNCTAD, 2016). While the reduction or even the removal of barriers (tariffs and non-tariffs) to trade between WAEMU member countries should be a catalyst for intra-zone trade in general and for Ivory Coast in particular, what are the determinants of Ivory Coast intra-regional trade? Are the factors of agglomeration economy not implemented in the economic and commercial dynamics of the WAEMU? Hence the interest of this study in which the concern is how the infrastructure variables and the economic environment, source of positive externalities, influence Ivory Coast intra-WAEMU trade?

The contribution of this work is to provide an analysis of the impact of infrastructure and the economic environment on Ivory Coast intra WAEMU exports. In addition, it takes into account a similarity index that captures the degree of economic convergence of WAEMU member countries. The underlying intuition lies in the fact that the similarity of the production systems of the WAEMU member countries would limit the potential for intra-Community trade. Therefore, even the leading economy does not sufficiently capture the benefits of potential agglomeration effects even less the other members. There would be a disconnection between the center and the periphery.

The rest of the paper is organized as follows. Section 1 reviews the literature on the determinants of intra-African trade by focusing on key factors (identified as catalysts or inhibitors) such as infrastructure and economic environment variables. Section 2 presents the methodology. Section 3 analyzes some descriptive statistics on Ivory Coast intra WAEMU trade with regard to correlation with the infrastructure variables on one hand and the economic environment's on the other hand. Section 4 offers comments on the main results of the 
econometric analysis. Section 5 concludes and outlines some recommendations.

\section{Literature Review}

This paper could be part of the general problem of the determinants of intra-African trade flows in general and of trade within a Regional Economic Community (REC) in Africa, such as the West African Economic and Monetary Union (WAEMU) in particular. Thus, it analyzes the influence of infrastructure and the economic environment variables on Ivory Coast intra-regional exports. In this section, it discusses some empirical studies that have analyzed the determinants of intra-African trade by focusing on factors such as infrastructure and the economic environment.

Limão and Venables (2001) find that, in sub-Saharan Africa, the quality of infrastructure is a powerful factor explaining the level and the dynamics of trade. Particularly, they show that the lack of infrastructure limits economic transactions between African countries. Indeed, according to them, the inadequacy of these infrastructures and the poor quality lead to an increase in transaction costs and reduce trade. Another factor has been pointed out by Rodrick (1997). According to him, the downward trend in Africa's trade and low participation in world and intra-African trade are explained by the low economic growth in these economies. Hence, an increase in GDP leads to an increase in trade, while the distance between partners reduces trade flows (Norehan, Hussin, \& Hadi, 2014). The distance between economies is a limiting factor of trade as they appear as transaction costs. The higher are the transaction costs, the lower is the traffic between the trading countries (Wang, Wei, \& Liu, 2010).

Moreover, population growth in the partner countries encourages more exports in general. In terms of trade openness, barriers to trade are strongly correlated with the degree of openness of the economy (Norehan, Hussin, \& Hadi, 2014). At the same time, the level of macroeconomic variables as well as the similarity between economies in terms of economic performance, net inflows of FDI and production of innovations are positively correlated with trade flows.

Longo and Khalid (2004) analyzed the determinants of intra-African trade by highlighting potential barriers to the expansion. They showed that the state of infrastructures, the gaps in the communication and transport network, inhibits intra-African trade. Moreover, the adoption and the management of macroeconomic policy, such as exchange rate policy, promote intra-regional trade according to them. Particularly in terms of infrastructure, quality and quantity are important as well as ancillary services - for example the supply of banking services and ease of access to financing - are important sources of positive externalities for exporters. So according to them, infrastructure variables, the management of policy are able to foster trade expansion between members of RECs in Africa.

The quality of infrastructures and institutions is important determinant not only of the volume of exports but also above all of the decision to export. Indeed, good quality institutions favor the growth of imports as well as exports (Anderson \& Marcouiller, 2002). The difference in the quality of institutions is a source of comparative advantage (Linders, HL Slangen, De Groot, \& Beugelsdijk, 2005). Such institutions contribute to reducing the transaction costs of economic agents and facilitate trade. As a result exporters and/or importers benefiting from good quality institutes are more competitive and more dynamic in trade with the rest of the world. The performance of exports and the propensity to participate actively in international trade depend on the quality of the institutions and the access of economic agents to the transport and communication infrastructures developed (Francoisa \& Manchin, 2007). Several studies have been conducted on the 
determinant of trade flows in WAEMU. Some of them did not focus on the specific impact of infrastructure and economic environment variables on trade flows. Membership in the WAEMU zone (Gbetnkom \& Avom, 2005) and the conduct of economic reforms contribute to the expansion of trade within WAEMU member states in terms of import and export diversion (Agbodji, 2007). However, Agbodji (2007) shows that the expansion of unofficial trade, significantly reduces trade in WAEMU. It should be noted that the positive impact of the creation of WAEMU on intra-union trade is reduced over time and is strongly influenced by Ivory Coast's performance (Gbetnkom \& Avom, 2005; Egger \& Pfaffermayr, 2013; AfDB, 2013).

Ultimately, the weakness of intra-African trade is explained by several factors. The quality of infrastructure, the quality of institutions, in particular the stability of the political environment and the absence of violence, the macroeconomic environment, and the management of macroeconomic policy, all have an impact on trade between WAEMU member countries. According to Longo and Sekkat (2004), this study examines the impact of infrastructure variables and the economic environment on intra-WAEMU trade of Ivory Coast from 1996 to 2013. The following section presents the research methods.

\section{Research Methods}

The analysis is based on a transformed gravity model. This section presents the specification of the gravity model and the estimation method and the data.

\section{Econometric Specification and Estimation Method}

The original specification of the gravity model based on the physical relationship links the partner country's GDP and the distance between them. By applying it to exports, the traditional equation is written:

$$
\text { Export }_{t j}=A \frac{G D P_{i}^{\theta} G D P_{j}^{\theta}}{D i s \tan c e_{i j}^{\mu}}
$$

The gravity model has generally been applied to cross section data. But Matyas (1997) revealed the inadequacies of this approach. This is for example the wrong specification. He suggests that the gravity model should take into account temporal effects. In this same line, Egger (2000) argues that the gravity model in panel would be more appropriate. For these reasons, following Kumar and Shahid (2015), this analysis uses with panel data. Doing so, the study can capture the relationships between variables over time and, it allows for unobservable estimates (Rahman, 2007). The basic specification in panel used in this paper is given by the following equation:

$$
\operatorname{Export}_{i j, t}=A \frac{G D P_{i t}^{\theta} G D P_{j t}^{\theta}}{D_{i j}^{\mu}}
$$

With $\mathrm{i}$ as Ivory Coast, $\mathrm{j}$ is the partner country of WAEMU and $\mathrm{t}$ designates years. A is a scale parameter. Export $_{i j, t}$ stands for the value of exports from Ivory Coast towards a member country of WAEMU at year $t$. $G D P_{i t}, G D P_{j t}$ and $D_{i j}$ represent respectively the Gross Domestic Product (GDP) of Ivory Coast, the GDP of the partner member of WAEMU, the distance between the two countries. Subsequently, the empirical work considered an advanced model with the addition of control variables in equation (3):

$$
\operatorname{Export}_{i j, t}=A \frac{G D P_{i t}^{\theta} G D P_{j t}^{\theta}}{D_{i j}^{\mu}} e^{\gamma X_{i j t}}
$$


With a set of control variables and traditional variables of the model of severity such as membership to a zone, sharing a common language, sharing a common border, and so on, in this study in addition to these extensions, we will focus on the scale factor $\mathrm{A}$.

According to Wang, Wei, and Liu (2010), A is a function. This function specifies the interactions between the infrastructure variables and variables related to the economic environment of Ivory Coast and its partners. Others authors have set this relationship also (Balasubramanyam, Salisu, \& Sapsford, 1996; Coe \& Helpman, 1995, Coe, Helpman, \& Hoffmaister, 1997). These factors - infrastructure variables and economic environment ones, according to the new geographical economy, are sources of positive externalities to boost exports of Ivory Coast and induce ripple effects across the union (Egger \& Pfaffermayr, 2013).

The infrastructure variables used in this analysis are: road quality availability $(\mathrm{R})$, the percentage of paved roads, percentage of the population using a mobile phone (Mob). The variables of the economic environment are the indicator of political stability and absence of violence (SP) as well as the net flows of foreign direct investment (FDI). In the view of the literature, the above mentioned variables influence the export capacities of a country. Thus, the scale factor A was specified as follows depending on each country, and also on time. This approach makes it possible to take into account in the analysis, the heterogeneity not only between countries in terms of trade performance but also over time in terms of efforts made to create more favorable conditions to expand trade. So the factor A could be written as follows:

$$
A_{i j, t}=e^{a} F D I_{i, t}^{\beta_{1}} F D I_{j, t}^{\beta_{2}} S P_{i, t}^{\beta_{3}} S P_{j, t}^{\beta_{4}} R_{i, t}^{\beta_{5}} R_{j, t}^{\beta_{6}} M_{i, t}^{\beta_{7}} M_{j o b_{j, t}^{\beta_{8}}}^{\beta_{1}}
$$

With $\alpha$, a constant that captures the effect of variables not taken into account in the model the other parameters represent a decomposition of the positive external effects of infrastructures and economic environment variables on Ivory Coast intra-WAEMU exports.

By combining equations (3) and (4), and transforming with the logarithmic function, the final specification is written as follows:

$$
\begin{aligned}
\operatorname{InExport}_{i j t}= & \alpha+\beta_{1} \operatorname{InFDI}_{i t}+\beta_{2} \operatorname{InFDI}_{j t}+\beta_{3} \operatorname{InSP}_{i t}+\beta_{4} \operatorname{InSP}_{j t}+\beta_{5} \operatorname{InR}_{i t}+\beta_{6} \operatorname{InR}_{j t} \\
& +\beta_{7} \operatorname{InMob}_{i t}+\beta_{8} \operatorname{InMob}_{j t}+\theta \operatorname{InGDP}_{i t}+\vartheta \operatorname{InGDP}_{j t}-\mu I n D_{i j}+\gamma X_{i j t}+\varepsilon_{i j t}
\end{aligned}
$$

With $\varepsilon_{\mathrm{ijt}}=\mu_{\mathrm{ij}}+\mu_{\mathrm{t}}+\mu_{\mathrm{ijt}}, \mu_{\mathrm{ij}}$ represents the error term due to each pair of countries that do not depend on time, $\mu_{\mathrm{t}}$ the error term due to time that does not depend on country pairs and $\mu_{\mathrm{ijt}}$ the error term that takes into account the variation of time and each country pair at a time. In order to take into account the null values, the dependent variable Export is the result of the transformation of the gross bilateral export variable plus 1. It is assumed that the non-existence of certain pairs of countries from one year to the next corresponds to zero values.

\section{Data}

Data used in this analysis are annual, from 1996 to 2013 for the eight member states of WAEMU. Table 1 shows each variable, the source as well as the units of measurement and the expected signs.

Foreign direct investment (FDI) inflows are treated as a proxy of investor confidence in the economy. They also report on the good management of economic policy, which promises good prospects for growth and development (Longo \& Sekkat, 2004). Therefore, it is assumed that if an economy is very attractive, this indicates good economic policy management. Then for economic environment variables and FDI inflows, the 
expected signs are positive. As far as it concerns infrastructure variables (road, mobile phone) it is supposed that improving them must generate positive external effects and generate more trade flows. So the expected sign is positive. On the contrary distance represents a proxy variable for transaction costs and an increase leads to reducing trade flows. So the expected sign is negative.

Table 1

Description of Data, Variables, and Expected Signs

\begin{tabular}{|c|c|c|c|}
\hline Variables & Sources & Measuring units & Expected signs \\
\hline $\begin{array}{l}\text { Bilateral exports between Ivory Coast } \\
\text { and WAEMU member countries (Export) }\end{array}$ & $\begin{array}{l}\text { International Monetary Fund, } \\
\text { Direction of Trade Statistics }\end{array}$ & USD (units) & \\
\hline Gross Domestic Product (GDP) & UNCTAD database & $\begin{array}{l}\text { In millions of USD, at current prices, } \\
\text { current exchange rate }\end{array}$ & Positive \\
\hline Distances (between capitals) (D) & CEPII database & In $\mathrm{km}$ & Negative \\
\hline $\begin{array}{l}\text { Political stability and absence of violence } \\
\text { (SP) }\end{array}$ & $\begin{array}{l}\text { World Bank, World } \\
\text { Governance Indicators }\end{array}$ & Score & Positive \\
\hline Percentage of paved roads $(\mathrm{R})$ & $\begin{array}{l}\text { World Bank, World } \\
\text { Development Indicators }\end{array}$ & Percentage & Positive \\
\hline $\begin{array}{l}\text { Number of people using mobile phone } \\
\text { (Mob) }\end{array}$ & $\begin{array}{l}\text { World Bank, World } \\
\text { Development Indicators }\end{array}$ & Percentage & Positive \\
\hline Foreign Direct Investment (FDI) & UNCTAD database & $\begin{array}{l}\text { In millions of USD at current and } \\
\text { current exchange rates }\end{array}$ & Positive \\
\hline Opening onto the sea (OS) & The author & $\begin{array}{l}\text { Take the value } 1 \text { if the partner has a } \\
\text { border opened on the sea and } 0 \text { if no }\end{array}$ & Positive \\
\hline Similarity in terms of GDP & Wang, Wei, and Liu (2010) & See equation (6) & Positive \\
\hline
\end{tabular}

\section{Research Results}

\section{Descriptive Statistics}

The first two charts on the first line of Figure 1 show that an increase in the percentage of paved roads in Ivory Coast would lower exports towards WAEMU countries. The linear fit line has a negative slope (graphical quadrant in the northwest of Figure 1). This result is not intuitive. When the percentage of paved roads in the other WAEMU member countries increases, intra-regional exports of Ivory Coast increase. The linear fit line has a positive slope (graph in the northeast quadrant of Figure 1). This is an expected result as having a high proportion of paved roads indicates the availability of relatively good quality road infrastructure. Consequently, this would considerably reduce delivery times, transport costs and encourage more exchanges between Ivory Coast and its partners in the union. This linear relation seems fragile because the coefficient of correlation is negative and significant $(-0.24)$.

For the number of mobile phone subscribers, both in Ivory Coast and among its regional partners, an increase in the number of subscribers would lead to an increase in intra WAEMU exports, all things being equal. Indeed, the increase in the number of mobile phone subscribers also reduces transaction costs by facilitating communication between partners. As a result, the more telephone subscribers, the easier it is to communicate and the lower the transaction costs. Therefore, increasing the number of mobile phone subscribers is favorable to the increase of intra WAEMU trade in Ivory Coast as shown in the last two graphs in Figure 1. Both linear fit lines have positive slopes. This positive relationship is confirmed by the linear correlation coefficients between the intra-WAEMU exports of Ivory Coast and the percentage of mobile phone subscribers in both Ivory Coast and the partner countries of the union. They are respectively 0.33 and 0.35 . These coefficients are significant at 5\% level. 


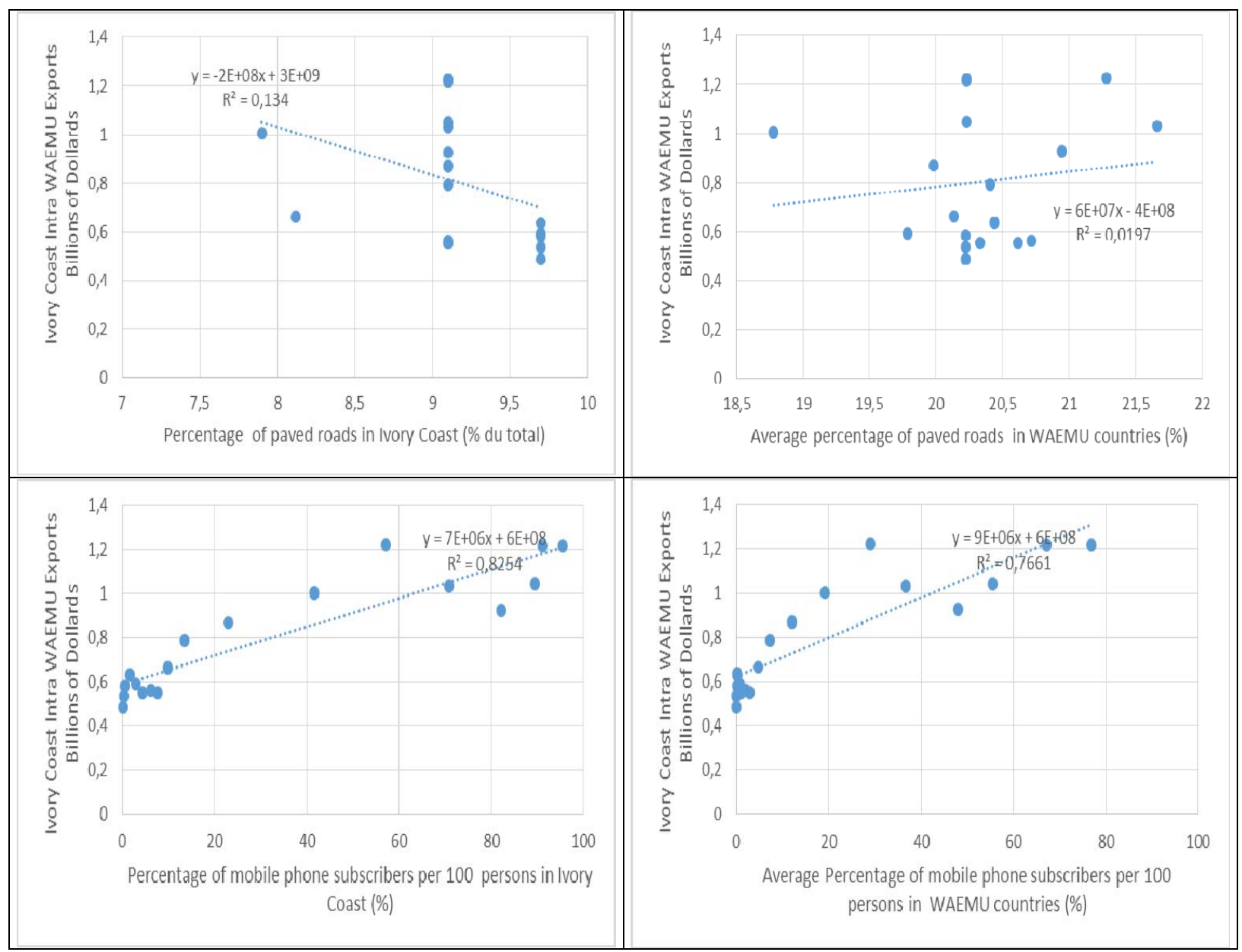

Figure 1. Evolution of Ivory Coast intra-WAEMU exports according to level of infrastructure variables.

Net inflows of FDI would be favorable to the expansion of intra-WAEMU exports of Ivory Coast. In Figure 2, graphs of northwest and northeast quadrants, linear adjustment lines have positive slopes. Indeed, the increase in net inflows of FDI would indicate good macroeconomic policy management which would result in a better performance of the productive system in Ivory Coast. Good performances could thus lead to an increase in exports as productive investments increase. It is noted, however, that the linear adjustment is not of good quality. Moreover, the coefficient of linear correlation between intra-WAEMU exports of Ivory Coast and FDI inflows is positive but not significant. On the other hand, among the relatively less efficient partners, an inflow of FDI could lead to an increase in import demand from Ivory Coast, in a center-periphery configuration (Ivory Coast being the center of the WAEMU union and the other countries, the periphery). The linear correlation coefficient is positive and significant at the $5 \%$ level $(0.25)$.

Concerning the political environment, the descriptive analysis presents results which are not intuitive. It appears from the latest graphics (southeast and southwest quadrants of Figure 2) the strengthening of stability and absence of violence is not conducive to the expansion of intra WAEMU Ivory Coast. However, the linear correlation coefficient between intra-WAEMU exports and the indicator of political stability in the partner countries are positive and significant at the $5 \%$ level. It is 0.19 . This indicates that there is a positive statistical relationship between the political environment in the WAEMU partner countries and the intra-regional exports 
of Ivory Coast.

According to Wang, Wei, and Liu (2010), a similarity index of partner countries was introduced in the analysis. This index reflects the similarity of countries in terms of GDP. It should be noted that the higher is the GDP, the greater will be the demand for exports. It is calculated for each year for each country pair, using the following formula:

$$
\operatorname{Sim}_{i j}=1-\frac{G D P_{i}^{2}}{\left(G D P_{i}+G D P_{j}\right)^{2}}-\frac{G D P_{j}^{2}}{\left(G D P_{i}+G D P_{j}\right)^{2}}
$$

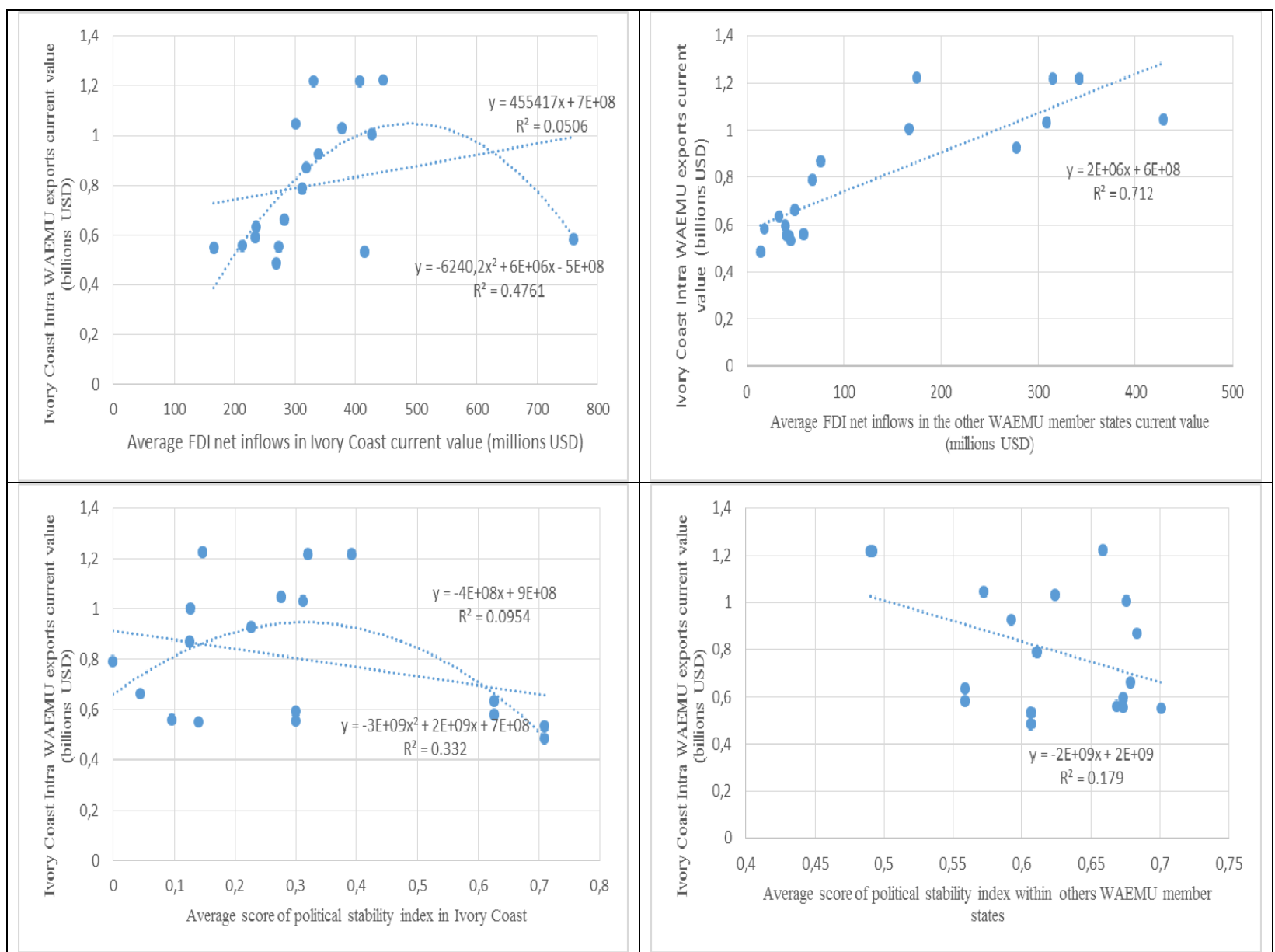

Figure 2. Evolution of Ivory Coast intra-WAEMU exports with FDI net inflows and the political stability score.

It captures the relative size of partner countries in terms of GDP in each period. Its value varies between 0 and 0.5 with the value 0 which corresponds to an absolute divergence of the size of the countries studied and 0.5 denotes an equality of the relative sizes of the countries. Thus, the more the value of the index tends towards 0.5 , the more the countries are similar. And if countries are similar this could translate into a large share of intra-industry trade in total trade, hence a high proportion of intra-union trade (Wang, Wei, \& Liu, 2010). The calculations show that the similarity index of Ivory Coast and its WAEMU partners is between 0.25 and 0.33 with a mean of 0.29 and a standard deviation of 0.03 .

The interpretation of this value seems fragile because the mean is close to 0.25 and the standard deviation is 
very low. However, the coefficient of variation (the ratio between the standard deviation and the arithmetic mean) of this indicator is 0.10 less than 0.15 . So, Ivory Coast and its WAEMU partners are not divergent from a GDP perspective between 1996 and 2013. The relative sizes of these countries are not very different. The coefficient of variation of the similarity index shows that these economies are relatively homogeneous in terms of GDP. This situation should favor further intra-WAEMU trade. Figure 3 shows that exports intra WAEMU Ivory Coast between 1996 and 2013 would increase with the similarity index all (under ceteris paribus assumption).

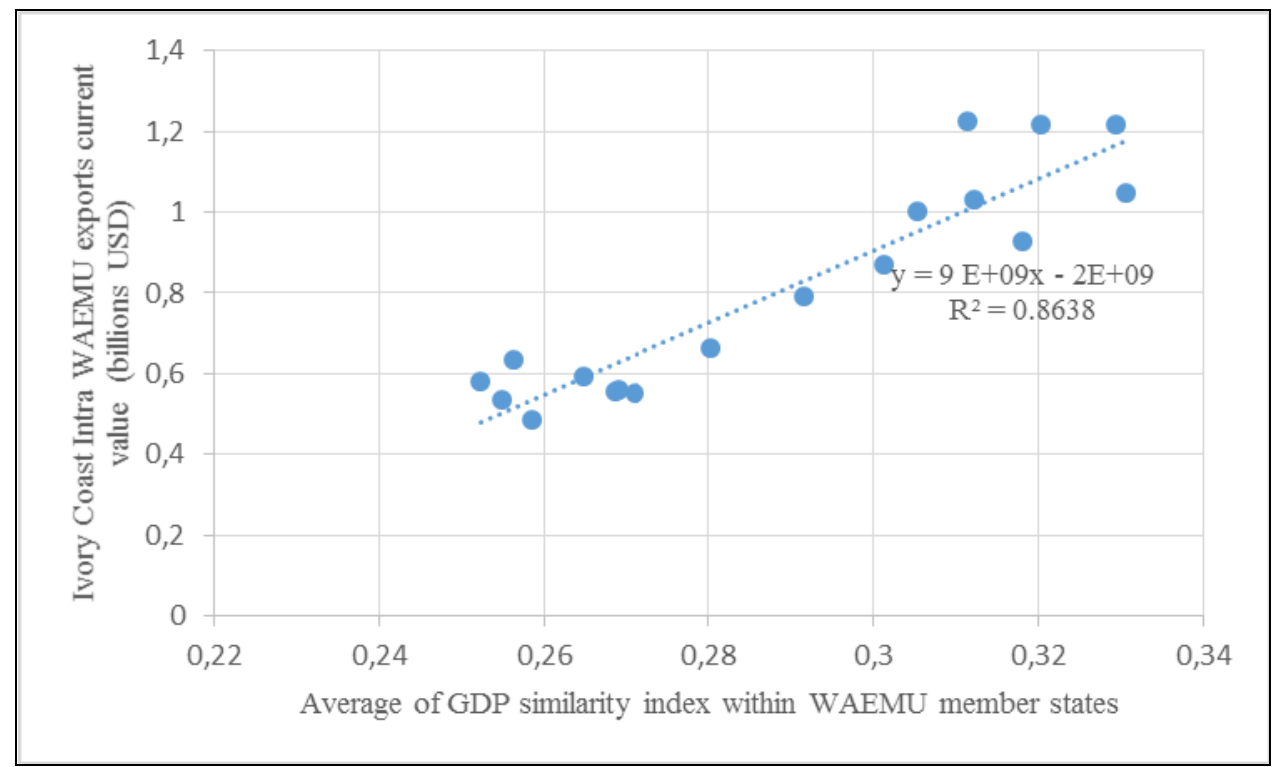

Figure 3. Evolution of Ivory Coast intra-WAEMU exports with the GDP similarity index within member states.

This descriptive analysis suggests the statistical relationship between intra-WAEMU exports of Ivory Coast and environmental factors as well as infrastructure. The estimation of the model (Equation (5)) will make it possible to examine them more closely. This is the focus of the next section, which also focuses on the traditional variables of the gravity model.

\section{Estimations Results and Discussions}

The Haussmann test on the full model leads to non-rejection of the random effects model. Estimates of the four (4) panel models with random effects are performed by correcting heteroskedasticity and controlling the (potential) heterogeneity of time and individuals. The same is true for the estimation by the ordinary least squares (OLS) method. The estimates were realized step by step by integrating the variables of interest in the equation as and when they occur. Two sets of estimates have been made: the first with the infrastructure variables and the second with the variables of the economic environment. All estimates are served as controls of the robustness of the sign of the coefficients associated with the variables of interest. This section has two parts. The first analyzes the influence of transport and communication infrastructures on intra-WAEMU exports of Ivory Coast while the second examines the effects of the economic environment. In the table of results, we are interested in the estimation of column (4) in which fixed time and individual effects are controlled. Table 2 presents the results of the full model. 
Influence of transport and communication infrastructures. The variables used here to analyze the effect of transport and communication infrastructures on intra-WAEMU exports in Ivory Coast are: the percentage of paved roads in relation to total roads and the percentage of mobile telephone subscribers. Estimates show that an increase in the proportion of paved roads in Ivory Coast has a positive and significant impact on intra-WAEMU exports of Ivory Coast.

A $1 \%$ point increase in the percentage of paved roads in Ivory Coast leads to a $3.37 \%$ increase in the value of intra-WAEMU exports of Ivory Coast. Similarly, a $1 \%$ point increase in the percentage of people using the mobile phone in Ivory Coast, leads to an increase in exports of $0.67 \%$. These results are in line with those of Francoisa and Manchin (2007). The performance of exports and the propensity to participate actively in international trade depend on the access of economic agents to the developed transport and communication infrastructures. Indeed, access to high-quality transport and communication infrastructures contributes to the reduction of transaction costs. This reduction in costs encourages the expansion of trade and hence the propensity to export.

Influence of the economic environment. The variables used to analyze the influence of the economic environment both in Ivory Coast and in other WAEMU countries on intra-WAEMU exports in Ivory Coast are: changes in GDP and population, net incoming FDI flows, and the co-traders' similarity index.

Estimations show that changes in GDP, net inflows of foreign direct investment (FDI) entering Ivory Coast, and the similarity index influence the intra-WAEMU exports of Ivory Coast.

Economic growth in WAEMU countries has a positive and significant impact on Ivory Coast's exports towards WAEMU. A $1 \%$ increase in GDP in the partner countries, leads to an increase in the value of intra-WAEMU exports of Ivory Coast by about 3.7\%. This result is in line with the findings of the gravity model estimates in other empirical studies (Longo \& Sekkat, 2004; Gbetnkom \& Avom, 2005; Agbodji, 2007). From the point of view of the importing countries, the increase in GDP in the importing countries corresponds to an increase in income. And this increase in income translates into an increase in demand for final consumer goods, intermediate goods, capital goods in the countries concerned, ceteris paribus. In so far as the domestic production of these importing countries does not cover this demand, the latter uses imports, in particular from Ivory Coast. From the point of view of Ivory Coast, exporting country, this increase in income represents potential outlets for exporting companies in Ivory Coast.

A $1 \%$ growth of the GDP of Ivory Coast leads to $7.6 \%$ decline in its exports towards the union. It is a counter-intuitive result that could be explained by the fact that economic growth in Ivory Coast results from an increase in the production of goods whose demand is low or non-existent in the WAEMU. Economic growth in Ivory Coast is based on the expansion of primary products, notably coffee, cocoa, and minerals. These products are exported raw to non-WAEMU partners for processing. Also, this result could reflect a disconnection between the economic dynamics of the Ivory Coast and that of the union. Positive external effects are not present.

In terms of foreign direct investment (FDI), net inflows to Ivory Coast have a positive impact on exports. A $1 \%$ increase in net inflows of FDI leads to an increase of $2.09 \%$ in intra-WAEMU exports of Ivory Coast. This result suggests that FDI inflows to Ivory Coast are complementary to the expansion of Ivory Coast's foreign trade. It was noted in the descriptive statistics that intra-WAEMU trade in Ivory Coast is expanding. This expansion, which is accompanied by an entry of IDE, shows that Ivory Coast is attractive. Thus the 
investors settling there participate in the increase of the wealth, therefore of the national production. Consequently, the increase in production increases Ivory Coast's export potential, all things being equal.

Table 2

Estimations Results

\begin{tabular}{|c|c|c|c|c|c|}
\hline \multicolumn{6}{|c|}{ Dependent variable: Ln of the intra-WAEMU exports value of Ivory Coast ${ }^{1}$} \\
\hline $\begin{array}{l}\text { Explanatory variables transformed } \\
\text { into } \ln \text { except marked* variable and } \\
\text { constant }\end{array}$ & $(1)$ & $(2)$ & (3) & (4) & (OLS) \\
\hline GDP of Ivory Coast & $\begin{array}{l}-3.239 * * \\
(1.298)\end{array}$ & $\begin{array}{l}-6.639 * * * \\
(1,368)\end{array}$ & $\begin{array}{l}-2.938^{* * *} \\
(0.964)\end{array}$ & $\begin{array}{l}-7.563 * * * \\
(0.993)\end{array}$ & $\begin{array}{l}-3.239^{* *} \\
(1.506)\end{array}$ \\
\hline GDP of the WAEMU partner & $\begin{array}{l}3.905 * * * \\
(1,303)\end{array}$ & $\begin{array}{l}3.644^{* *} \\
(1.585)\end{array}$ & $\begin{array}{l}3.792 * * * \\
(1.116)\end{array}$ & $\begin{array}{l}3.698 * * * \\
(1.319)\end{array}$ & $\begin{array}{l}3.905 * * * \\
(1.387)\end{array}$ \\
\hline Population of Ivory Coast & $\begin{array}{l}-9.412 \\
(7,561)\end{array}$ & $\begin{array}{l}-3.058 \\
(8.373)\end{array}$ & $\begin{array}{l}-7.301 \\
(8.673)\end{array}$ & $\begin{array}{l}0.929 \\
(8.840)\end{array}$ & $\begin{array}{l}-9.412^{* *} \\
(3.796)\end{array}$ \\
\hline Population of the WAEMU partner & $\begin{array}{l}3.836^{* * *} \\
(1.014)\end{array}$ & $\begin{array}{l}4.280 * * * \\
(1,250)\end{array}$ & $\begin{array}{l}1.863 \\
(3.144)\end{array}$ & $\begin{array}{l}1.925 \\
(2.952)\end{array}$ & $\begin{array}{l}3.836 * * * \\
(0.943)\end{array}$ \\
\hline Distance & $\begin{array}{l}-2.732 * * * \\
(0.560)\end{array}$ & $\begin{array}{l}-2.587 * * * \\
(0.728)\end{array}$ & $\begin{array}{l}-2.129 \\
(2.371)\end{array}$ & $\begin{array}{l}-1.705 \\
(2.081)\end{array}$ & $\begin{array}{l}-2.732 * * * \\
(0.493)\end{array}$ \\
\hline Net inflows of FDI into Ivory Coast & $\begin{array}{l}0.398 \\
(0.250)\end{array}$ & $\begin{array}{l}1.593 * * * \\
(0.401)\end{array}$ & $\begin{array}{l}0.385 \\
(0.266)\end{array}$ & $\begin{array}{l}2.093 * * * \\
(0.426)\end{array}$ & $\begin{array}{l}0.398 \\
(0.305)\end{array}$ \\
\hline $\begin{array}{l}\text { Net flows of FDI into other } \\
\text { WAEMU countries }\end{array}$ & $\begin{array}{l}-0.004 \\
(0.053)\end{array}$ & $\begin{array}{l}-0.009 \\
(0.060)\end{array}$ & $\begin{array}{l}-0.000 \\
(0.052)\end{array}$ & $\begin{array}{l}0.000 \\
(0.059)\end{array}$ & $\begin{array}{l}-0.004 \\
(0.046)\end{array}$ \\
\hline Percentage of mobile phone & 0.119 & $0.615 *$ & 0.093 & $0.674 * *$ & 0.119 \\
\hline subscribers in Ivory Coast & $(0.153)$ & $(0.335)$ & $(0.116)$ & $(0.330)$ & $(0.264)$ \\
\hline $\begin{array}{l}\text { Percentage of mobile phone subscribers in } \\
\text { other WAEMU countries }\end{array}$ & $\begin{array}{l}0.078 \\
(0.153)\end{array}$ & $\begin{array}{l}0.080 \\
(0.134)\end{array}$ & $\begin{array}{l}0.066 \\
(0.144)\end{array}$ & $\begin{array}{l}0.068 \\
(0.131)\end{array}$ & $\begin{array}{l}0.078 \\
(0.106)\end{array}$ \\
\hline Percentage of paved roads in Ivory Coast & $\begin{array}{l}0.464 \\
(0.421)\end{array}$ & $\begin{array}{l}2.532 * * * \\
(0.839)\end{array}$ & $\begin{array}{l}0.740 \\
(0.501)\end{array}$ & $\begin{array}{l}3.373 * * * \\
(1.042)\end{array}$ & $\begin{array}{l}0.464 \\
(1.588)\end{array}$ \\
\hline Percentage of tarred roads in other & 0.190 & 0.186 & $\begin{array}{l}-0.333 \\
(0289)\end{array}$ & -0.343 & $\begin{array}{l}0.190 \\
(0187)\end{array}$ \\
\hline $\begin{array}{l}\text { Political stability index and absence } \\
\text { of violence in Ivory Coast }\end{array}$ & $\begin{array}{l}0.079 \\
(0.175)\end{array}$ & $\begin{array}{l}-0.230 \\
(0.349)\end{array}$ & $\begin{array}{l}0.082 \\
(0.152)\end{array}$ & $\begin{array}{l}(0.283) \\
-0.147 \\
(0.329)\end{array}$ & $\begin{array}{l}0.079 \\
(0.144)\end{array}$ \\
\hline $\begin{array}{l}\text { Political stability index and absence } \\
\text { of violence in other countries of the } \\
\text { WAEMU }\end{array}$ & $\begin{array}{l}0.056 \\
(0.102)\end{array}$ & $\begin{array}{l}0.048 \\
(0.101)\end{array}$ & $\begin{array}{l}0.206 \\
(0.203)\end{array}$ & $\begin{array}{l}0.190 \\
(0.171)\end{array}$ & $\begin{array}{l}0.056 \\
(0.140)\end{array}$ \\
\hline Having a common border* & $\begin{array}{l}0.664 \\
(0.623)\end{array}$ & $\begin{array}{l}0.892 \\
(0.801)\end{array}$ & $\begin{array}{l}0.340 \\
(0.902)\end{array}$ & $\begin{array}{l}0.657 \\
(0.816)\end{array}$ & $\begin{array}{l}0.664 * \\
(0.369)\end{array}$ \\
\hline Opening onto the sea* & $\begin{array}{l}2.014 * * * \\
(0.688)\end{array}$ & $\begin{array}{l}2.346^{* * *} \\
(0.875)\end{array}$ & $\begin{array}{l}1.133 \\
(1.710)\end{array}$ & $\begin{array}{l}1.232 \\
(1.660)\end{array}$ & $\begin{array}{l}2.014 * * * \\
(0.555)\end{array}$ \\
\hline Similarity index of countries & $\begin{array}{l}-7.352^{* * * *} \\
(1.725)\end{array}$ & $\begin{array}{l}-7.462 * * * \\
(1.834)\end{array}$ & $\begin{array}{l}-6.024 * * * \\
(2.086)\end{array}$ & $\begin{array}{l}-6.345 * * * \\
(2.389)\end{array}$ & $\begin{array}{l}-7.352 * * * \\
(2.501)\end{array}$ \\
\hline Constant & $\begin{array}{l}117.122 \\
(114.386)\end{array}$ & $\begin{array}{l}27.521 \\
(123.471)\end{array}$ & $\begin{array}{l}110.919 \\
(116.184)\end{array}$ & $\begin{array}{l}0.636 \\
(120.935)\end{array}$ & $\begin{array}{l}117.122 * * \\
(58.324)\end{array}$ \\
\hline Number of observations & 109 & 109 & 109 & 109 & 109 \\
\hline Fisher F statistics (19.89) & - & - & - & - & 44.37 \\
\hline $\begin{array}{l}\text { Critical probability associated with } \mathrm{F} \\
(\text { Prob }>\text { F) }\end{array}$ & - & - & - & - & 0.00 \\
\hline $\mathrm{R}^{2}$ adjusted OLS & - & - & - & - & 0.892 \\
\hline Fixed time effects & No & Yes & No & Yes & No \\
\hline Fixed effects individuals & No & No & Yes & Yes & No \\
\hline
\end{tabular}

Note. Robust standard errors in parentheses, $* * * p<0.01, * * p<0.05, * p<0.1$.

\footnotetext{
1 The gross value of exports was increased by one to take account of zero values. We considered that for missing country pairs, the value is also zero.
} 
The similarity index has a negative impact on intra-WAEMU exports of Ivory Coast. An increase in the index of one point leads to a drop in intra-WAEMU exports of Ivory Coast of $6.34 \%$. This indicator varies between 0.25 and 0.33 . As discussed in the previous section, WAEMU economies are similar in terms of GDP and the trade potential between Ivory Coast and other WAEMU countries is falling over the period of analysis. This result shows that there is no connection between the center and the periphery. This disconnection does not favor the expansion of intra-regional exports in Ivory Coast. This result could confirm the negative sign obtained in the relationship between the intra-regional exports of Ivory Coast and the GDP of Ivory Coast. One reason is the lack of complementarity between the production systems of Ivory Coast and the other WAEMU member countries. Indeed, the complementarity of the branches of production is low, the industrial fabric is highly concentrated and the content of exports of manufactured goods with high added-value intra-WAEMU is limited. The tables in annexes 5 and 6 show the top selling products in the WAEMU countries in general. The structure of intra-WAEMU exports is still dominated by low value-added products.

\section{Conclusion}

This paper examines the role of infrastructure and the economic environment on Ivory Coast intra-regional trade. The study performs a transformed and advanced gravity model, using panel data over the period 1996 to 2013, modelling exports of Ivory Coast. The analysis shows exports towards the other member states of WAEMU depend significantly on the availability of transport and communication infrastructures developed as well as variables such as GDP growth, economic similarity within countries, FDI net inflows in Ivory Coast. Estimations point out that indeed, the level of economic growth in the other member countries, FDI net inflows in Ivory Coast, the number of mobile phone subscribers per 100 inhabitants in Ivory Coast and the proportion of paved roads, have a positive impact on Ivory Coast intra-regional trade.

It should be noted that the level of economic growth in Ivory Coast has a negative impact on intra-WAEMU exports of Ivory Coast. Moreover, the disconnection between the center and the periphery is a reality in WAEMU because the index of similarity negatively influences intra-WAEMU exports of Ivory Coast. The complementarity of production systems is limited and this constitutes a brake on the expansion of intra-WAEMU trade in Ivory Coast. A possible extension of this study would be to carry out an analysis at the product level. It will make it possible to highlight the level of intra-industry trade and will thus be able to deepen the question of the integration of production systems in WAEMU. However, in order for Ivory Coast, the leading economy, the center of WAEMU to exert ripple effects on the rest of the union, the other member countries and the periphery, the following recommendations are made with regard to results of the study:

- Carry on efforts to upgrade the road infrastructure in Ivory Coast and WAEMU and proceed with the implementation of projects such as the Yamoussoukro-Ouangolodougou-Burkina Faso border highway (still under study, Regional Economic Programm (REP) tracking report, March 2016);

- Rethink interconnection to mobile networks in the member states in order to allow access to the greatest number and at a lower cost;

- Facilitate border operations by reducing harassment: to ensure the proper implementation of the directives and measures set in the framework of the development of regional trade (17th report of the Observatory of Abnormal Practices (OAP)), there are still illegal removals on the corridors going to Abidjan;

- Exploit potential demand by adapting demand to the tastes and preferences of consumers in the union;

- Continue efforts to improve the business environment and manage macroeconomic policy in order to 
increase the economic attractiveness of the union;

- Strengthen the multilateral monitoring mechanism of the Union with a view to consolidating the achievements of the convergence, solidarity, and growth pact.

\section{References}

Agbodji, A. E. (2007). Intégration et échanges commerciaux intra sous-régionaux: le cas de l'UEMOA. Revue africaine de l'Intégration, 1(1), 161-188.

Anderson, J. E., \& Marcouiller, D. (2002). Insecurity and the pattern of trade: An empirical investigation. Review of Economics and Statistics, 84(2), 342-352.

AfDB (African Development Banque). (2013, July). http://www.afdb.org/uploads/tx_llafdbpapers/Impact_des_Unions_Montaires_sur_les_changes_commerciaux._Le_cas_de_1 UEMOA_V4.pdf. Récupéré sur http://www.afdb.org: http://www.afdb.org

Balasubramanyam, V. N., Salisu, M., \& Sapsford, D. (1996). Foreign direct investment and growth in EP and IS countries. Economic Journal, 106, 92-105.

Coe, D. T., Helpman, E., \& Hoffmaister, A. W. (1997). North-South R\&D spillovers. Economic Journal, 107, $134-149$.

Egger, P. (2000). A note on the proper econometric specification of the gravity equation. Economics Letters, 66, 25-31.

Egger, P. H., \& Pfaffermayr, M. (2013). The pure effects of European integration on intra-EU core and periphery trade. The World Economy, 36(6), 701-712.

International Monetary Fund. (2016). Union Economique et Monétaire Ouest-Africaine, Rapport des services du FMI sur les politiques communes des pays membres. Washington, D.C.: Fonds Monétaire International.

Francoisa, J., \& Manchin, M. (2007). Institutions, infrastructure, and trade. Economics Working Paper No. 77.

Gbetnkom, D., \& Avom, D. (2005). Intégration par le marché: le cas de l'UEMOA. Region et développement, (22), 6.

Kumar, S., \& Shahid, A. (2015). Gravity model by panel data approach: An empirical application with implications for South Asian countries. Foreign Trade Review, 50(4), 233-249.

Limão, N., \& Venables, A. J. (2001). Infrastructure, geographical disadvantage, transport costs, and trade. The World Bank Economic Review, 15(3), 451-479.

Linders, G. J., HL Slangen, A., De Groot, H. L., \& Beugelsdijk, S. (2005). Cultural and institutional determinants of bilateral trade flows. Tinbergen Institute Discussion Paper, No. 05-074/3.

Longo, R., \& Sekkat, K. (2004, August). Economic obstacles to expanding intra-African trade. World Development, 32(8), 1309-1321.

Matyas, L. (1997). Proper econometric specification of the gravity model. The World Economy, 20(3), 363-368.

Nayo, A., \& Egoumé-Bossogo, P. (2011). Feeling the elephant's weight: The impact of Ivory Coast's crisis on WAEMU trade. IMF Working Papers, 1-32.

Norehan, A., Hussin, A., \& Hadi, M. O. (2014). The determinants of trade and trade direction of Arab Maghreb Union (AMU). Journal of Empirical Economics, 2(2), 46-62.

Rahman, M. M. (2007, June). The causative factors of Bangladesh's exports: Evidence from the gravity model analysis. In Proceedings of the 48th Annual Conference of the New Zealand Association of Economists (pp. 1-47). New Zealand Association of Economist, New Zealand: New Zealand Association of Economist.

Rodrik, D. (1997). Trade policy and economic performance in sub-Saharan Africa. NBER Working Paper, No. 6562, NBER, Cambridge, Mass.

UNCTAD. (2016, May 10). http://unctad.org/en/Pages/Statistics.aspx. Récupéré sur http://unctad.org: http://unctad.org

Wang, C., Wei, Y., \& Liu, X. (2010). Determinants of bilateral trade flows in OECD countries: Evidence from gravity panel data models. The World Economy, 33(7), 894-915. 